\title{
Endoscopic findings of colorectum in patients presenting with bleeding per rectum
}

\author{
Makkie A. K. Alyouzbaki \\ From the Endoscopy Unit, Department of Medicine, Al-Salam Teaching Hospital, Mosul, Iraq. \\ Correspondence: Makkie A.K. Alyouzbaki. Youz.makkee@yahoo.com. \\ (Ann Coll Med Mosul 2013; 39 (2): 178-181). \\ Received: $26^{\text {th }}$ Aug. 2012; Accepted: $18^{\text {th }}$ Jun. 2013.
}

\section{ABSTRACT}

Objectives: To determine the causes of bleeding per rectum in patients undergoing flexible colorectal endoscopy, taking in consideration the frequency of serious causes in our locality, and to compare the results with others.

Patients and methods: A retrospective descriptive study done at Al-Salam Teaching Hospital, endoscopy unit, Mosul, Iraq. One hundred and eighty five patients underwent flexible colorectal endoscopy between January 2008 and December 2011 complaining of bleeding per rectum, biopsies were taken from lesions and sent for histopathology then the findings were tabulated and recorded.

Results: One hundred and eighty five patients, with mean age of 44 years, and a male:female ratio of 2.36:1. One hundred and twenty patients $(64.86 \%)$ had hemorrhoids, 10 patients $(5.4 \%)$ had hemorrhoids and fissure in ano, 20 patients $(10.8 \%)$ had carcinoma, 14 patients $(7.5 \%)$ with inflammatory bowel disease, 9 patients $(4.8 \%)$ with non-specific proctitis and colitis, 9 patients $(4.8 \%)$ had polyps, 2 patients $(1.1 \%)$ with solitary rectal ulcer, and 1 patient $(0.5 \%)$ had benign tumor.

Conclusion: An appreciable number of serious lesions was found in patients with rectal bleeding especially in those above 40 years of age.

Keywords: Rectal bleeding, sigmoid-colonoscopy.

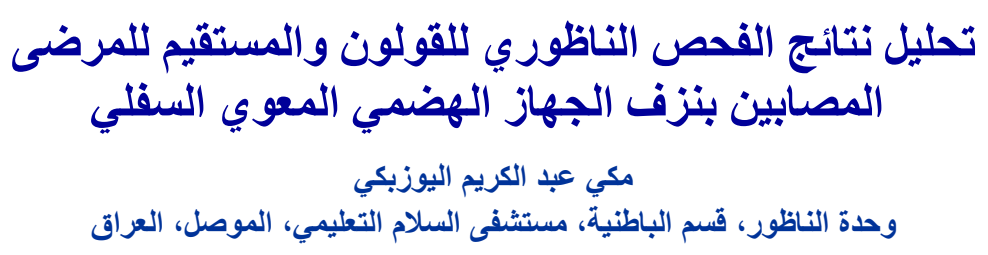

الخلاصة

الأهداف: لتحليل نتائج تنظير الجهاز الهضمي السفلي (المستقيم و القولون) للمرضى المحالين الىى وحدة التنظير في مستشفى السلام

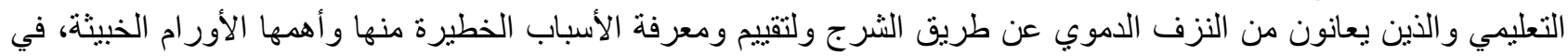

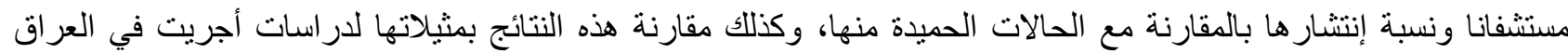

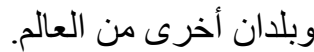

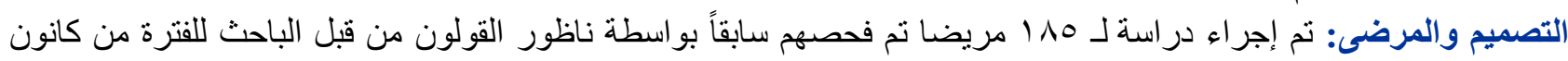

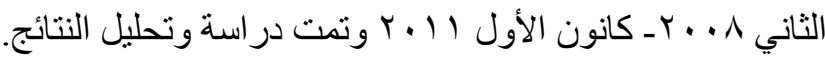

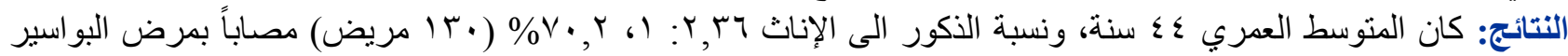

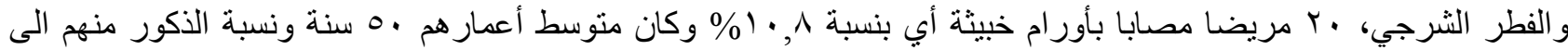

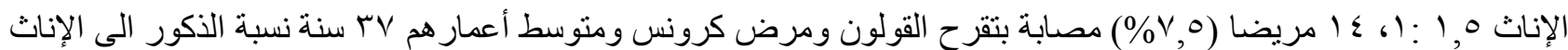

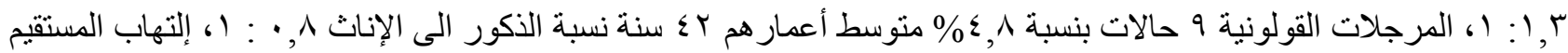

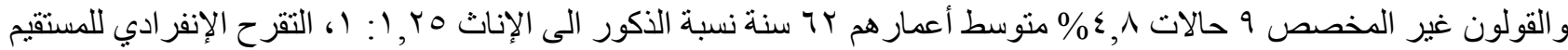

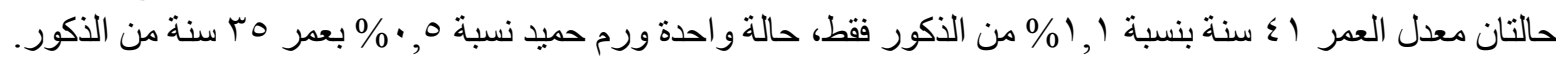

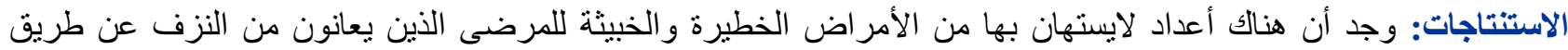
الثرج في مستشفى السلام التعليمي وخصوصات لاعنا للفئات العمرية أكثر من أربعين عاما. 


\section{INTRODUCTION}

$\mathrm{B}$ leeding per rectum is a common problem, approximately one in seven persons between the ages of 20 and 64 years have an attack of bleeding that requires medical help. ${ }^{1,2}$ It remains a diagnostic challenge on the basis of bleeding alone to distinguish between benign anal lesions and serious colorectal diseases. ${ }^{3}$ Bleeding anal lesions especially hemorrhoids and fissures are frequent causes of rectal bleeding that could coexist with colorectal carcinoma and endoscopy is indicated in these cases. ${ }^{4,5}$

Lower gastrointestinal bleeding refers to any bleeding distal to the ligament of Trietz. The color of stool and the volume of bleeding are good indicators of the site of bleeding. Black tarry stool, medically referred to as melena, can occur in upper Gl tract, also can occur from small bowel and proximal colon. Bright red stool is a sign of fast moving active bleeding. ${ }^{6,7}$ Lower gastro intestinal bleeding commonly seen at emergency, is usually less in frequency than upper $\mathrm{Gl}$ bleeding. ${ }^{8}$ Approximately $85 \%$ of lower gastrointestinal bleeding involves the colon and $10 \%$ involves the upper Gl tract and $3 \%-5 \%$ are of small bowel origin. Mortality rate from lower GI tract bleeding is $2 \%-4 \% .{ }^{9}$ Lower gastrointestinal endoscopy is used to investigate myriad of symptoms due to diseases of rectum and colon. Colorectal endoscopy is mandatory in average risk patients who are fecal occult blood positive. ${ }^{10,11}$ The procedure aids in the diagnosis of premalignant lesions and early carcinoma and significantly reduces the mortality of colorectal carcinoma. ${ }^{5,12}$

Iraq shares the epidemiological characteristics of colorectal cancer of developing countries in the Middle East, but a shift towards the western-style of living is leading to the increase of colon and rectal cancer incidence. ${ }^{13}$

\section{PATIENTS AND METHODS}

This is a retrospective study from January 2008 to December 2011 of one hundred and eighty five patients who were referred to the endoscopy unit, at Al Salam Teaching Hospital, Mosul, Iraq, who underwent colonoscopy by the author using Olympus Japan SN-2510583/CF-P10 Storz video colonoscopy SN1349. All patients included in the study were complaining of bleeding per rectum, whether fresh blood or mixed with mucus. Patients who had upper GIT bleeding, acute bloody diarrhea and bleeding diathesis were excluded from the study. All patients were informed about the way of preparation. In most of the patients, the rectum and the left side of the colon were visualized, biopsies were taken from the lesions and sent to the pathology laboratory of our hospital and to private laboratories. All the findings and results were documented and tabulated according to their occurrence and seriousness in the endoscopy unit and some of the lesions were photographed.

\section{RESULTS}

One hundred and eighty five patients (185) were examined by flexible colorectal endoscopy from January 2008 to December 2011, their mean age was 44 years, and male:female ratio of 2.36:1. One hundred and thirty patients $(70.2 \%)$ with mean age of 44.5 years and a male to female ratio of 3.3:1 (120 patients had hemorrhoids only, and 10 patients had both hemorrhoids and fissure in ano). Twenty patients (10.8\%) with mean age of 50 year, and male:female ratio of $1.5: 1$ had malignant tumors of mucin secreting adenocarcinoma of moderate and poor differentiation, all of them were found in the rectum, sigmoid and descending colon. Fourteen patients $(7.5 \%)$ with mean age of 37 years, and male:female ratio of $1.33: 1$ had inflammatory bowel disease, 12 patients had ulcerative colitis, and 2 patients had Crohn's disease. Nine patients $(4.8 \%)$ with mean age of 42 years, and male: female ratio of $0.8: 1$ had polyps; 4 of them had single polyp, and the remaining five had multiple adenomatous polyps, 3 of the latter had severe dysplastic changes. Nine patients $(4.8 \%)$ with mean age of 62 years, and male:female ratio of 1.2:1 had proctocolitis, 7 of them with non-specific type, the remaining two had psuedomembranous colitis. Two male patients $(1.1 \%)$ aged $38 \& 47$ years had solitary rectal ulcer. One 35 years old male patient $(0.5 \%)$, had metaplastic polyp, (Table 1). 
Table 1. Summary of the results.

\begin{tabular}{|c|c|c|c|}
\hline $\begin{array}{l}\text { Type of } \\
\text { lesions }\end{array}$ & $\begin{array}{c}\text { No. of } \\
\text { patients \& \% }\end{array}$ & $\begin{array}{c}\text { Mean } \\
\text { age } \\
\text { years }\end{array}$ & Male:female \\
\hline $\begin{array}{l}\text { Haemorrhoids } \\
\& \text { fissure in ano }\end{array}$ & $\begin{array}{c}130,70.2 \% \\
120 \text { had } \\
\text { hemorroids } \\
10 \text { with } \\
\text { fissure in ano }\end{array}$ & 44.5 & 3.33:1 \\
\hline $\begin{array}{l}\text { Colorectal } \\
\text { carcinoma }\end{array}$ & $\begin{array}{c}20 \\
10.8 \%\end{array}$ & 50 & $1.5: 1$ \\
\hline Benign tumor & $\begin{array}{c}1 \\
0.5 \%\end{array}$ & 35 & $1: 0$ \\
\hline Polyps & $\begin{array}{c}9 \\
4.8 \%\end{array}$ & 42 & $0.8: 1$ \\
\hline $\begin{array}{l}\text { Inflammatory } \\
\text { bowel diseases } \\
\text { Ulcerative, } \\
\text { Crhon's }\end{array}$ & $\begin{array}{c}14 \\
7.5 \%\end{array}$ & 37 & $1.33: 1$ \\
\hline $\begin{array}{l}\text { Non-specific } \\
\text { proctatitis, } \\
\text { colitis }\end{array}$ & $\begin{array}{c}9 \\
4.8 \%\end{array}$ & 62 & $1.25: 1$ \\
\hline $\begin{array}{l}\text { Solitary rectal } \\
\text { ulcer }\end{array}$ & $\begin{array}{c}2 \\
1.1 \% \\
\end{array}$ & 41 & $2: 0$ \\
\hline Total & 185 & 44 & $2.36: 1$ \\
\hline
\end{tabular}

\section{DISCUSSION}

The use of flexible colorectal endoscopy in screening people with rectal bleeding resulted in a significant reduction in both the incidence and the mortality from colorectal carcinoma in many communities. ${ }^{14-17}$ Our retrospective study in Mosul was designed to identify the pattern of colorectal diseases in patients presented with bleeding per rectum. Twenty patients out of one hundred and eighty five were discovered to have malignant tumors which constituted (10.8\%) from the total and this result is consistent with similar study done in Iraq by Talib A- Majid et $a l,{ }^{18}$ but is much more higher than a similar study done in Hong Kong in Queen Marry Hospital in which the result was $1.2 \% .{ }^{19}$ It is a bit higher than the percentage seen in Egypt, ${ }^{20}$ and also higher than those reported at Korle -Bu Teaching Hospital, by Da Kubo et al in Ghana (6.7\%). ${ }^{21}$ Grossly, malignant tumors were of different patterns. Histologically, they were varied from moderately differentiated to poorly differentiate adenocarcinoma. The mean age was 50 year, and a male:female ratio of $1.6: 1$ which is not consistent with the Egyptian and other international reports. ${ }^{22-24}$ The high percentage of malignant tumors in our study may be partly attributed to the change of life style to that of the western countries, and partly to the exposure of our population to depleted uranium. ${ }^{25}$ Inflammatory bowel disease was found in 14 patients (7.5\%) which is much lower than a study in Egypt $(37.5 \%),{ }^{25}$ and also much less than the Iraqi study done by Shubbar et al $(71 \%){ }^{26}$ The figure is higher than that of the Ghana study. ${ }^{21}$ The age of the patients with inflammatory bowel disease was similar to the Iraqi study mentioned above. There were 9 patients $(4.8 \%)$ with polyps, 5 of them had multiple polyposis with histopatholgical dysplasia and their mean age was 42 year, the figure is higher than those of Ghana study $(2.9 \%)^{21}$ but less than a study done by Winawer SJ et al. ${ }^{27}$

Nine cases with non-specific proctitis and colitis $(4.8 \%)$, were seen, the number is lower than the of the Iraqi study done by Shubbar et $a .^{26}$ Solitary rectal ulcer syndrome was diagnosed in 2 patients representing $1.1 \%$ compared to $3.5 \%$ of Amira et $a^{26}$ similar to that of Sharara. ${ }^{28}$ One patient presented with bleeding per rectum had metaplastic polyp at rectosigmoid area.

\section{CONCLUSION}

The study revealed that there was appreciable number of serious lesions especially cancer of the large bowel in advanced stages presented with bleeding per rectum.

\section{REFERENCES}

1. Christie JP. Flexible sigmoidoscopy-why, where and when? Am J Gastroenterol 1980;73:70-2.

2. Talley NJ, Jones M. Self-reported rectal bleeding in a United States community: prevalence, risk factors, and health care seeking. Am J Gastroenterol 1998;93:217983.

3. Raftery TL, Samson N. Cancer of the colon: a clinical correlation between Presenting symptoms and survival. Am Surg. 1980 Nov;46(11):600-606.

4. Acosta JA, Fournier TK, Knutson CO, Ragland JJ. Colonoscopic evaluation of rectal bleeding in young adults. Am Surg. 1994 Nov;60(11):903-906.

5. Rex DK, Johnson DA, Lieberman DA, Burt RW, Sonnenberg A. Colorectal cancer prevention: screening recommendations of the American College of Gastroenterology. Am J Gastroenterol. 2000 Apr;95(4): 868-877.

6. Helfand M, Marton KI, Zimmer-Gembeck MJ, Sox HC. History of visible rectal Bleeding in primary care population. Initial assessment and 10-year follow up. JAMA 1997 Jan 1;277(1):44-48.

7. Vernava AM, Longo WE, Virgo KS. A nationwide study of the incidence and etiology of lower gastrointestinal bleeding. Surg Res Commum. 1996;18: 113-120.

8. Colacchio T A, Forde K A, Patsos T J, et al. Impact of modern diagnostic methods on the management of active rectal bleeding ten years experience. Am J S urg 1982;143(5):607-10. 
9. Walfso A B, ed. Harwood -NUSS clinical practice of emergency medicine. $4^{\text {th }}$ ed. Wolters Kluwer: Lippincott Williams \& Williams; 2005.p.349-352.

10. Gilbertsen VA. Proctosigmoidoscopy and polypectomy in reducing the incidence of rectal cancer. Cancer. 1974 Sep;34(3):936-939.

11. Bretthauer M. Evidence for colorectal screen. Best Pract Res Clin Anasthesiol 2010;24 (4):417-25.

12. Newcomb PA, Norfleet RG, Storer BE, Surawicz TS, Marcus PM. Screening sigmoidoscopy and colorectal cancer mortality. J Natl Cancer Inst. 1992;84(20):15721575

13. AL-Bahrani Z, H-Humadi A. Epidemiology of colon and rectal cancer in Iraq. World Journal of Colorectal Surgery 2008; $1(1): 15$.

14. Byers $T$, Levin $B$, Rothenberger $D$, Dodd GD, Smith RA. American Cancer Society guidelines for screening and surveillance for early detection of colorectal polyps and cancer: update 1997. CA Cancer J Clin. 1997 MayJun;47(3):154-160.

15. Mandel JS, Bond JH, Churh TR, Snover DC, Bradley GM, Schuman LM, et al. Reducing mortality from colorectal cancer by screening for fecal occult blood. N Engl J Med. 1993;328(19):1365-1371.

16. Hardcastle JD, Chamberlain JO, Robinson MHE, Moss SM, Amar SS, Balfour TW, et al. Randomised controlled trial of faecal-occult-blood screening for colorectal cancer. Lancet 1996 Nov 30; 348(9040):1472-1477.

17. Kronborg O, Fenger C, Olsen J, Jorgensen OD, Sondergaard $\mathrm{O}$. Randomised study Of screening for colorectal cancer with faecal-occult-blood test. Lancet. 1996 Nov 30;348(9040):1467-1471.

18. Majid TA, Shakir WM, Mahmmod AS, et al. Colorectal carcinoma presentation and mangment. Iraqi P G M J 2009;8(3):204-211.

19. Choi HK, Law WL, Chu KW. The value of flexible sigmoidoscopy for patients with bright red rectal bleeding. Hong Kong Med J 2003;9(3):171-4.
20. The Pattern of Colonic Diseases in Egypt: A Colonoscopic study. Arab J Gastroenterol 2006;7(2):5358

21. Da Kubo JCB, Kumoji R, Naaeder SB, Clegg Lamptey JN. Endoscopic Evaluation of the Colorectum in Patients Presenting with Haematochezia at Korle-Bu Teaching Hospital Accra. Ghana med j 2008;42(1):3337.

22. Barsoum H. Cancer in Egypt: Its incidence and clinical forms. ActaUnio Int Contra Cancrum 1953;9(2): 241-50.

23. McLeod HL, McKay JA, Collie Duguid ES, et al. Therapeutic opportunities from tumour biology in metastatic colon cancer. Eur J Cancer 2000;36(13): 1706-12

24. Bond J. Colorectal cancer update. Prevention, screening, treatment and surveillance for high-risk groups. Med Clincs North Am 2000;84:1163-82.

25. AL-Azzawi SN. The Responsibilty of U.S in contaminating iraq with depleted uranium, the Kuala Lumpur International Conference to Criminalise War, Putra World Trade Centre, October 2009.p.28-31.

26. Shubbar $\mathrm{AH}$, Fayadh $\mathrm{MH}$. Chronic colitis: clinical, endoscopic and histological evaluation of 130 iraqi patients. IJGE 2001;1(1):11-17.

27. Winawer SJ, Zauber AG, O'Brien MJ, et al. The national polyp study: design, methods, and characteristics of patients with newly diagnosed polyps. The national polyp study workgroup. Cancer 1992; 70(Suppl 5):1236-45.

28. Sharara AI, Azar C, Amr SS, Haddad M, Elobeidi MA. Solitary rectal ulcer syndrome: endoscopic spectrum and review of the literature. Department of internal medicine, American University of Beirut. Gastrointestinal endoscopy 2005; 62(5):755-62. 